\title{
DEVELOPMENT OF INFORMATION COMPETENCE VIA E-LEARNING
}

\section{Roman HRMO - Daniel KUČERKA}

\begin{abstract}
The aim of this contribution is to inform the reader about the problems and results of the research of the thesis work on the development of informative competece by e-learning. We also tried to indicate the relation between the education and the communicative and informative technologies. The contribution also informs about the results of the research and the quality of the prepared e-learning educational text for the subject Engineering production for secondary vocational schools for 1 st class of subsructure study in the field 64764 technical - economical worker. The research was implemented by the teachers of technical proffessional subjects and the students of secondary vocational schools with engineering approach SOŠA, SOŠ Senec and the teachers of engineering subjects with no engineering approach SOŠE Trnava. The research showed that the prepared thesis work fulfilled its goal, prepared e-learning educational text is better than the accessible textbooks and creates the alternative posibility for students studying independently.
\end{abstract}

Key words: competences, key competences, information competences, e-learning, e-learning text, pedagogical experiment.

\section{ROZVOJ INFORMAČNEJ KOMPETENCIE PROSTREDNÍCTVOM E-LEARNINGU}

Resumé: Ciel'om príspevku je uviest' čitatel'a do problematiky a výsledkov výskumu dizertačnej práce spracovanej na tému rozvoj informačnej kompetencie prostredníctvom e-learningu. Tu sme sa snažili naznačit' vzt’ah vzdelávania a komunikačných a informačných technológií. Príspevok d’alej informuje o výsledkoch výskumu dizertačnej práce a kvality e-learningového ícčebného textu určeného pre predmet Strojárska výroba pre stredné odborné školy pre 1. ročník nadstavbového štúdia v odbore 64764 technicko-ekonomický pracovník. Výskum bol realizovaný prostredníctvom učitel’ov technických profesijných predmetov a žiakov na stredných odborných školách so strojárskym zameraním SOŠA Trnava, SOŠ Senec a učitel'ov strojárskych predmetov s nestrojárskym zameraním SOŠE Trnava. Výsledky výskumu ukázali, že predložená dizertačná práca splnila predsavzatý ciel', pripravený e-learningový učebný text je lepší ako dostupné učebnice a tvorí im alternatívnu možnost' pri samostatnom štúdiu žiaka.

Kl'účová slova: kompetencie, klúčové kompetencie, informačné kompetencie, e-learning, e-learningový text, pedagogický experiment.

\section{1 Úvod}

Vedecko-technický rozvoj a informačnokomunikačné technológie zastávajú dôležitú úlohu v našom živote. V súčasnosti má e-learning významné miesto vo vzdelávaní. Používa sa väčšinou ako doplnková forma vzdelávania. Rozvoj nových technológií zasiahol aj do školstva. Informačno-komunikačné technológie zaujali dôležité miesto vo výchovnovzdelávacom procese. Predmet informatika významne zasahuje do výučby všetkých ostatných predmetov. Vd'aka týmto zmenám výučba sa stáva zaujímavejšia, dynamickejšia, pretože power - pointové prezentácie okrem obrázkov a textov môžu v sebe zahŕňat' aj videá alebo rôzne simulácie. Takto pripravená výučba prepojená s používaním interaktívnej tabule lepšie približuje žiakom danú problematiku.
Nové formy dištančného vzdelávania, kde e-learning nesporne patrí, sú otvoreným a pružným vzdelávaním. Takto sa otvorili d’alšie možnosti štúdia pre vel'ké množstvo študentov. E-learning je založený na poznávaní moderných technológií a ich používaní v praxi (napr. e-mail, internet, videokonferencie, mobily a pod.). Tento spôsob vzdelávania predkladá študentovi e-texty z rôznych oblastí vedy a tým zvyšuje informačnú kompetentnost' študentov (respondentov kurzu). Takéto študijné texty musia mat' dodržané špecifiká pre ich tvorbu.

\section{Kl'účové kompetencie}

Problematika klúčových kompetencií bola známa už od 70. rokov 19. storočia (D. Mertens, 1974) v súvislosti s problematikou zamestnanosti. Prvý zo strategických ciel'ov 
Lisabonského procesu (2000) je rozvíjat' kl'účové kompetencie $\mathrm{v}$ spoločnosti založenej na vedomostiach sa týka zlepšenia kvality a efektivity systémov vzdelávania. Pracovná skupina odborníkov začala od roku 2001 vytvárat' základ koncepcie $\mathrm{v}$ edukačných programoch.

Formovanie kl'účových kompetencií začalo $\mathrm{v}$ anglofónnom prostredí. Vývoj pojmom „basic skills“ pokračoval cez „competencies“ a skončil na pojme „key competencies“.

V kurikulu jednotlivých európskych štátov sa okrem pojmu klúčové kompetencie (napr. Rakúsko, Nemecko, flámska komunita v Belgicku) používajú rozlíšenia:

$>$ prahových a finálnych kompetencií (napr. valónska komunita v Begicku),

> základné komptencie (Španielsko, Luxembursko, Portugalsko),

\section{klúčové zručnosti (Vel'ká Británia).}

Kompetencia je správanie (činnost' alebo komplex činností), ktoré charakterizuje vynikajúci výkon v niektorej oblasti činnosti. Kl'účové kompetencie sú najdôležitejšie kompetencie z množiny kompetencií. Sú vhodné na riešenie celého radu väčšinou nepredvídatel'ných problémov, ktoré umožnia jedincovi úspešne sa vyrovnat' s rýchlymi zmenami v práci, osobnom a spoločenskom živote. (Hrmo, Turek 2003)

Kl'účové kompetencie sú pod záštitou EU definované ako prenosný a univerzálne použitel'ný súbor vedomostí, zručností a postojov, ktoré potrebuje každý jedinec pre svoje osobné naplnenie a rozvoj, pre zapojenie sa do spoločnosti a úspešnú zamestnatel'nost'. (Hučínová 2005)

Kompetencie podl'a referenčného rámca sa definujú ako kombinácia vedomostí, zručností a postojov primeraných danému kontextu.

Kl'účové kompetencie sú tie, ktoré potrebujú všetci jednotlivci na osobné uspokojenie a rozvoj, aktívne občianstvo, spoločenské začlenenie a zamestnanost'.

Referenčný rámec stanovuje osem
kl'účových kompetencií:
1. komunikácia v materinskom jazyku
2. komunikácia v cudzích jazykoch
3. matematická kompetencia a základné
kompetencie v oblasti vedy a techniky
4. digitálna kompetencia
5. naučit' sa učit'
6. spoločenské a občianske kompetencie
7. iniciatívnost' a podnikavost'

8. kultúrne povedomie a vyjadrovanie (Odporúčanie európskeho parlamentu a rady, 2006)

Odborníci sa zhodujú $\mathrm{v}$ tom, že klúčové kompetencie by si mali osvojit' všetci občania už počas povinného školského vzdelávania, ale aj v neformálnom vzdelávaní a rozvíjat' ich počas celého života, pretože sú hlavnou zbraňou jedinca ako uspiet' $\mathrm{v}$ konkurencii.

\section{Informačná kompetencia a e-learning}

Rozmach informácií vyvoláva stále väčšie protirečenie medzi obmedzenou kapacitou ludskej pamäti absorbovat' prudko narastajúce informácie, ktoré sa navyše rýchlo menia a zastarávajú.

Ovládanie práce $\quad \mathrm{s}$ informačnými a komunikačnými technológiami patrí medzi nevyhnutnú výbavu moderného človeka a patrí tiež medzi kl'účové kompetencie. Kompetencie bezprostredne súvisiace s informáciami sa nazývajú informačné kompetencie. V súvislosti $\mathrm{s}$ informačnými kompetenciami sa zvyknú používat' najmä pojmy:

- informačná gramotnost',

- počítačová gramotnost' a

-digitálna gramotnost' (Hrmo, Turek, 2003).

Počítačová gramotnost' je schopnost' pracovat' s najčastejšie využívaným programovým vybavením, schopnost' používat' internet $\mathrm{ku}$ komunikácii, k vyhl'adávaniu a spracovaniu informácií, schopnost' efektívneho využitia služieb a možností, ktoré moderná technológia ponúka.

Počítačovo gramotný jedinec musí byt' schopný minimálne základnej orientácie z každej oblasti.

Stotožňujeme sa stým, že informačná kompetencia sa skladá z podmnožín informačnej a počítačovej gramotnosti a je vhodná na riešenie celého radu úloh a nepredvídaných problémov a umožňuje tak jedincovi úspešne sa vyrovnat' s okamžitými zmenami v práci, v osobnom aj spoločenskom živote. Súčasná spoločnost' sa vyznačuje rýchlymi zmenami, vel'kým množstvom informácií a rýchlym tempom inovácií, najmä informačných. Preto ovládanie práce $\mathrm{s}$ informačnými a komunikačnými technológiami patrí medzi nevyhnutnú výbavu moderného človeka a patrí tiež medzi klúčcové kompetencie.

Jednou $\mathrm{z}$ najrozhodujúcejších požiadaviek rozvoja informačnej spoločnosti je zabezpečit' dostupnost' informácií a informačných služieb pre každého občana. 
Predpokladom pre zabezpečenie použitel'nosti informačných služieb a tým zabránit' vzniku kategórie občanov bez prístupu $\mathrm{k}$ informačnokomunikačným technológiám (IKT) je zabezpečit' základné digitálne vzdelanie (gramotnost'). Digitálne gramotný človek používa informačno-komunikačné technológie v každodennom živote.

Podl'a Kalaša a kol. (2006) digitálna gramotnost' je súhrn základných IKT zručností a pokročilejších zručností, ktoré umožňujú kreatívne a kriticky používat' digitálne nástroje a médiá.

Spôsob vzdelávania cestou IKT začína ovplyvňovat' spôsob a systém prípravy na výkon povolania a postupné získavanie a rozširovanie vedomostí počas aktívneho života.

Modely vzdelávania používané v oblasti informačnej kompetencie

Medzi najznámejšie modely používané $\mathrm{v}$ tejto oblasti patria:

* The Research Cycle 2000 - Výskumný cyklus

* The big6 - Problémové riešenie informačných zručností

E-Learning sú informácie o inej forme vzdelávania, ktorá v poslednej dobe prežíva svoj rozvoj. Dôvodom jeho zavedenia je doba a rýchlost' zmien v každodennom živote.

E-Learning $\mathrm{v}$ širšom slova zmysle znamená proces, ktorý popisuje a rieši tvorbu, distribúciu, riadenie výučby a spätnú väzbu na základe počítačových kurzov, ktorým stále častejšie hovoríme e-learningové kurzy. Tieto aplikácie väčšinou obsahujú simulácie, multimediálne lekcie, t.j. kombinácie textového výkladu $\mathrm{s}$ animáciami, grafikou, schémami, auditom, videom a elektronickými testami. Táto forma vzdelávania predstavuje vel'mi kvalitný doplnok existujúcich možností vzdelávania.

E-learnig podl'a tohto, akú komunikačnú technológiu využíva, sa spravidla delí na :

$$
\text { * on-line e-learning }
$$

Základný rozdiel medzi off-line a on-line učením je $\mathrm{v}$ potrebe pripojenia sa $\mathrm{k}$ nejakej počítačovej sieti.

Off-line učenie si vyžaduje iba počítač a nevyžaduje si trvalé pripojenie k sieti. Študijný materiál je distribuovaný prostredníctvom pamätových nosičov napr. CD-ROM, DVDROM. Tento spôsob je často využívaný vo vzdelávaní dospelých. Využíva sa často kombinovaná forma štúdia, forma samostatného štúdia je s prezenčnými tutoriálmi.

On-line učenie si vyžaduje trvalé pripojenie k počítačovej sieti. Študijné moduly sú distribuované a komunikácia prebieha prostredníctvom siete.

Didaktika tvorby učebného textu pre e-learning

Ked' porovnáme klasické a dištančné vzdelávanie, zistíme základný rozdiel v komunikácii a v pravidelnosti stretnutí. Tu je študent viazaný na učebný text. Text musí suplovat' učitel'a, a preto je najdôležitejšou zložkou kurzu

Vel'mi dôležitými rozdielmi pri spracovaní bežných učebných textov a učebných textov v e-lerningovom vzdelávaní sú:

$\checkmark \quad v$ prístupe $\mathrm{k}$ textom

$\checkmark \quad \vee$ dížke textov

$\checkmark \quad v$ definovaní ciel'ov

Učebné materiály sú len sprostredkovatel'om a nosičom informácií, študent musí preukázat' schopnosti samostatného spracovania informácií a materiály musia obsahovat' (Zlámal, 2009):

$>$ ciel'štúdia (témy)

$>$ obsah štúdia (témy) a väzby učiva na študijný odbor,

$>$ teoretický základ učiva v racionálnom členení vrátane doplňujúcich prvkov (obrázky, grafy, tabul'ky a pod.)

> multimediálna podpora teoretického základu učiva,

$>$ riešené úlohy a príklady, modelové situácie (spracovanie multimediálnou formu),

$>$ kontrolné otázky s klúčom riešenia,

$>$ odkazy na korešpondenčné úlohy,

$>$ rámcový časový harmonogram štúdia,

$>$ motivačné prvky,

$>$ zhrnutie,

$>$ záverečné testy,

$>$ slovník pojmov

$>$ zoznam literatúry a odkazov.

Pri ich tvorbe je potrebné sústredit' sa na dve oblasti, ktoré je pre dobrý výsledný efekt dôležité dodržiavat' a kombinovat': (Turčáni, 2005)

* didaktická - do tejto oblasti patria zásady, ktoré by mali spĺňat' základné požiadavky týkajúce sa tvorby aplikácie základných vyučovacích teórií do praxe;

* technická - tá by mala zahŕňat' vyriešenie všetkých požiadaviek, či hardwérových alebo softwérových. 
3 Priebeh a výsledky výskumu

Ciele výskumu

Hlavný ciel':

Hlavným ciel'om výskumu je spracovat' a vyhodnotit' e-learningový text na predmet Strojárska výroba pre 1. ročník študijného odboru technickoekonomický pracovník na SOŠE Trnava.

Čiastkové ciele:

K splneniu hlavného ciel'a výskumu je potrebné vykonat' tieto čiastkové ciele:

1.) Štatisticky vyhodnotit' vlastnosti spracovaného e-textu

2.) Porovnat' úroveň hodnotenia jednotlivých expertov

3.) Vyhodnotit' priemernú škálu hodnotenia vlastnosti e-textu

4.) Vyhodnotit priemernú zhodu $v$ hodnotiacich vlastnostiach

5.) Vypočítat' komplexnú mieru obtiažnosti e-textu

\section{6.) Zistit' čitatel'nost' e-textu}

\section{Predmet výskumu}

Výskum bol vykonávaný na SOŠE Trnava, SOŠA Trnava a SOŠ Senec. Predmetom výskumu je:

- tvorba textu pre e-learningový kurz

- vyhodnotenie kvality učebného textu pre elearningový kurz

- vyhodnotenie miery obtiažnosti textu pre elearningový kurz

- stanovenie čitatel'nosti textu pre elearningový kurz

Na výskume sa zúčastnili učitelia technických profesijných predmetov a žiaci nadstavbového štúdia SOŠA Trnava, SOŠ Senec a SOŠE Trnava, pre ktorých je e-learningový text určený. SOŠA Trnava, SOŠ Senec sú školy so strojárskym zameraním a SOŠE Trnava je škola, ktorej profilové odbory sú elektrotechnické.

\section{Hypotézy výskumu}

Hlavná (východisková) hypotéza: Spracovaný e-learningový text na predmet Strojárska výroba bude zvládnutel'ný v 1 . ročníku študijného odboru technickoekonomický pracovník na SOŠE Trnava.

Aby sme ju mohli overit', vyhodnotíme tieto výzkumné predpoklady:

\section{Viac ako $50 \quad \%$}

P1 vlastností bude hodnotená od 0 do +2 .

V Úroveň hodnotenia

P2 jednotlivých odborníkov bude viac ako $60 \%$.

V Priemerná škála hodnotenia

P3 vlastností učebného e-textu odborníkmi bude hodnotená nad $70 \%$.

V Percento dlhých slov v texte

P4 bude menej ako $50 \%$.

V Vybratá skupina študentov,

P5 pre ktorých je učebnica určená z vybratého textu doplní 13 a viac slov z 22 chýbajúcich slov.

V Hodnota Fog indexu bude 12

P6 alebo menej.

\section{Metódy výskumu}

Pri realizácii výskumu budú použité nasledovné výskumné metódy:

$>$ Expertné metódy - verifikácia výzkumných predpokladov č.: 1,2,3

$>$ Štatistické metódy - verifikácia výzkumných predpokladov č.: 4,5,6

Expertné metódy sa využivajú na hodnotenie primeranosti, zaujímavosti, zložitosti, metodické spracovanie alebo hodnotenia iných vlastností na základe výrokov pozorovatel'ov napr. učitel'ov, expertov, študentov a pod.

Expertnou metódou boli hodnotené výzkumné predpoklady VP1, VP2, VP3.

Štatistickými metódami môžeme skúmat' rôzne parametre týkajúce sa učiva získané meraním určitých vlastností učiva $\mathrm{v}$ učebnici.

$\mathrm{K}$ takýmto parametrom sa zahŕňa:

- critatel'nost' textu

- priemerný rozsah textu

- miera obtiažnosti učebného textu

Štatistickými metódami boli hodnotené výzkumné predpoklady VP4, VP5, VP6.

\section{Priebeh experimentu}

Experiment prebiehal $\mathrm{v}$ dvoch fázach. $\mathrm{V} 1$. fáze bola prípravná čast' experimentu a $\mathrm{v} 2$. fáze bola vyhodnocovacia čast' experimentu.

\section{Prípravná čast' experimentu}

V prípravnej časti experimentu sme riešili dve základné otázky:

- prípravu a spracovanie vhodnej obsahovej náplne jednotlivých kapitol (modulov) textu pre e-learningový kurz

- príprava dotazníka pre expertov (stredoškolských učitel'ov technických profesijných predmetov) a testu pre žiakov Vyhodnocovacia čast' experimentu

Táto čast' bola vykonávaná tiež $\mathrm{v}$ dvoch fázach. V prvej fáze boli vyhodnotené materiály 
od učitel'ov a v druhej fáze materiály vyhodnotené od žiakov.

\section{Dotazník pre expertov}

$\mathrm{V}$ 1. fáze výskumu hodnotilo spracovaný učebný text a obsahovú náplň 22 učitel'ov technických profesijných predmetov, z čoho bolo 7 učitel'ov SOŠA TT, 8 učitel'ov SOŠ SC (graf č. 1., os y) a 7 učitel'ov SOŠE TT (graf č. 2. - os y). Kvalita textu bola hodnotená pomocou škály $2,-1,0,1,2$ (graf č. $1,2-$ os x).

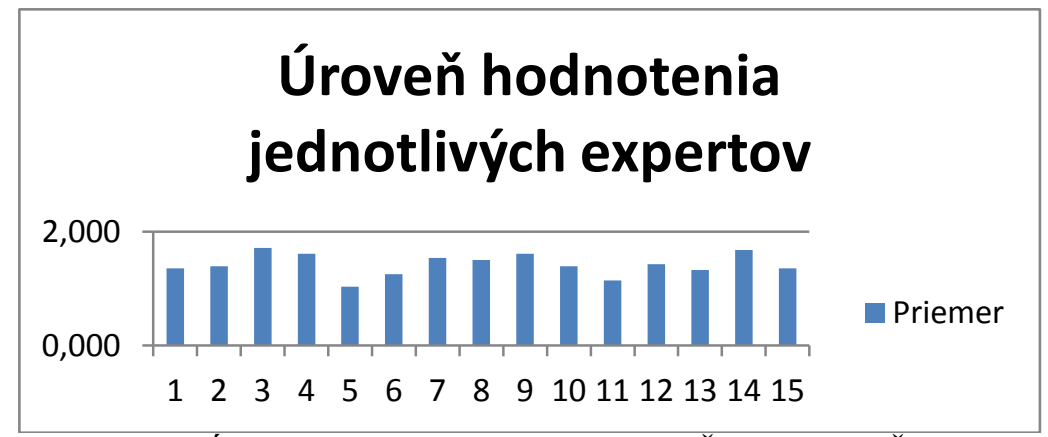

Graf 1 Úroveň hodnotenia expertov SOŠA TT a SOŠ SC

V spracovanom dotazníku najlepšie boli hodnotené položky c (jednoduchost' vyjadrovania) a $\mathbf{s}$ (ilustrácia učiva, obrázky, schémy, a pod.)) učitel'mi technických profesijných predmetov na školách so strojárskym zameraním, položky o (medzipredmetové vzt’ahy) a aa (metodické spracovanie textu) učitel'mi technických profesijných predmetov na škole s nestrojárskym zameraním. Naopak najslabšie bola hodnotená položka c (jednoduchost' vyjadrovania) učitel'mi technických profesijných predmetov na škole s nestrojárskym zameraním g (primeranost') technických strojárskym zameraním.

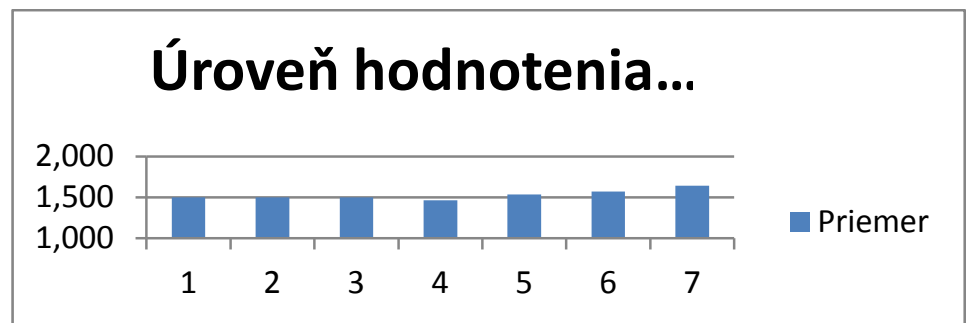

Graf 2 Úroveň hodnotenia expertov SOŠE TT

\section{Cloze test pre žiakov}

Cloze test bol rozdaný a vypĺňaný 91 žiakmi SOŠA TT, SOŠ SC, SOŠE TT (tab. 1) v školskom roku 2010/2011.

Tabul'ka1 Rozloženie žiakov po školách

\begin{tabular}{|l|c|c|}
\hline zameranie & $\begin{array}{c}\text { počet } \\
\text { žiakov }\end{array}$ & \% podiel \\
\hline SOŠA TT & 24 & $26,37 \%$ \\
\hline SOŠ SC & 31 & $34,07 \%$ \\
\hline SOŠE TT & 36 & $39,56 \%$ \\
\hline spolu & 91 & $\mathbf{1 0 0}$ \\
\hline
\end{tabular}

\section{Verifikácia výzkumných predpokladov} Verifikácia výzkumného predpokladu č. 1
VP1: Viac ako $50 \%$ vlastností bude hodnotených od 0 do +2

Výzkumný predpoklad 1 sme overovali dotazníkom pre expertov. Podl'a tohto dotazníka sme sa dozvedeli postoje odborníkov ke-učebnici na e-learningový kurz predmetu Strojárska výroba pre 1 . ročník nadstavbového štúdia. V dotazníku 22 odborníkov hodnotilo 616 vlastností (tabul'ka 2).

Tabul'ka 2 Hodnotenie vlastností

\begin{tabular}{|c|c|c|}
\hline $\mathrm{H}$ & $\begin{array}{c}\text { Poč. } \\
\text { vlastností }\end{array}$ & $\begin{array}{c}\% \\
\text { úspešnosti }\end{array}$ \\
\hline - & 0 & 0 \\
\hline 1 & 0 & 0 \\
\hline
\end{tabular}




\begin{tabular}{|l|l|l|}
\hline 0 & 23 & 3,73 \\
\hline 1 & 276 & 44,81 \\
\hline 2 & 317 & 51,76 \\
\hline$\sum$ & 616 & 100 \\
\hline
\end{tabular}

Graf 3 ukazuje, že experti hodnotili celkovo 616 vlastností čo predstavuje $100 \%$ škálou od -2 do 2 . Hodnotenie -2 a -1 nevyužili, v obidvoch prípadoch predstavuje $0 \%$. Hodnotenie 0 bolo v 23 prípadoch, čo predstavuje $3,73 \%$. Hodnotenie 1 využili v 276 prípadoch čo predstavuje $44,81 \%$ a hodnotenie 2 využili v 317 prípadoch, čo predstavuje $51,76 \%$.

Výzkumný predpoklad VP1 platí, pretože $100 \%$ vlastností bolo hodnotených v škále 0 do 2 .

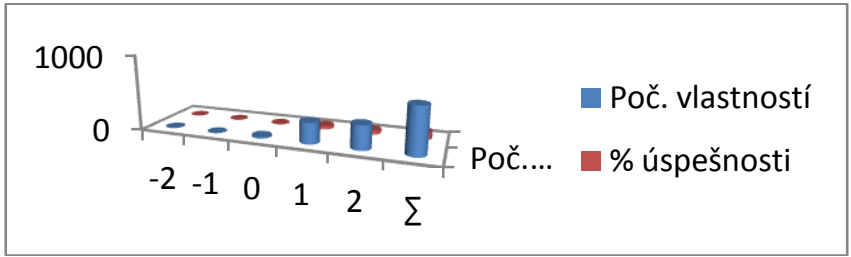

Graf 3 Hodnotenie vlastností

\section{Verifikácia výzkumného predpokladu č. 2}

VP2: Úroveň hodnotenia jednotlivých odborníkov bude viac ako $60 \%$

Výzkumný predpoklad 2 sme overovali dotazníkom pre expertov. Podl'a tohto dotazníka sme sa dozvedeli postoje odborníkov k e-učebnici na e-learningový kurz. Učitelia hodnotili položky v dotazníku priemernou známkou od 1,04 (čo predstavuje úroveň hodnotenia $52 \%$ ) do 1,71 (čo predstavuje úroveň hodnotenia $86 \%$ ).

Výzkumný predpoklad VP2 neplatí, pretože úroveň hodnotenia dvoch odborníkov nedosiahla $60 \%$
Verifikácia výzkumného predpokladu č. 3

VP3: Priemerná škála hodnotenia vlastností učebného e-textu odborníkmi bude hodnotená nad $70 \%$.

Výzkumný predpoklad 3 sme overovali dotazníkom pre expertov. Podl'a tohto dotazníka sme zistili, že pri hodnotení škôl, všetky tri školy hodnotili e-učebnicu pre e-learningový kurz v priemernej škále hodnotenia 1,48 a percentuálnej zhode nad $70 \%$, ako to ukazuje graf č. 4 a 5 .

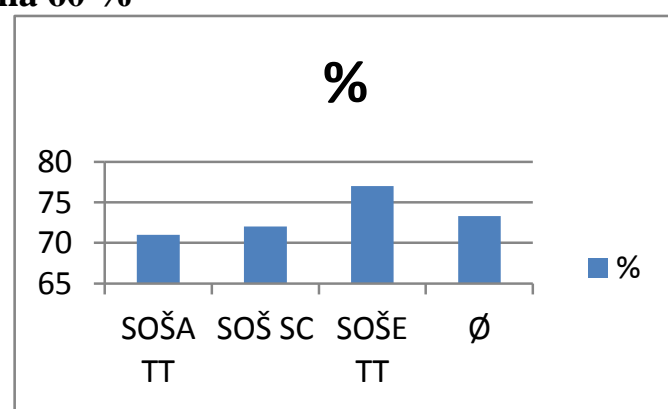

Graf 4 \%zhoda

Priemerná škála hodnotenia učitel'mi na SOŠA TT je 1,41 a percentuálna zhoda $71 \%$, na

SOŠ SC je 1,43 a percentuálna zhoda $72 \%$ a SOŠE TT je1,68 a percentuálna zhoda $77 \%$.

Podla vyhodnotenia dotazníka sa ukázalo, že priemerná škála hodnotenia učitel'ov

všetkých troch škôl je 1,48 a percentuálna zhoda $73,3 \%$.

Výzkumný predpoklad VP3 platí, pretože priemerná škála hodnotenia odborníkmi je 1,48 a percentuálna zhoda je nad $70 \%$.

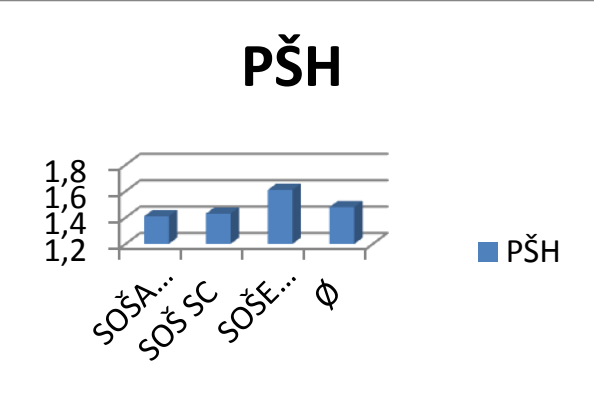

Graf 5 Priemerná škála hodnotenia

VP4: Percento dlhých slov v texte bude menej ako $50 \%$

V štatistickej metóde sme posudzovali náhodne vybraný text $\mathrm{z}$ každého modulu. Vybrané boli štyri texty, ktoré majú dížku: text 1 - 121 slov, text $2-108$ slov, text $3-111$ slov, text $4-111$ slov

Výpočet percentuálneho vyhodnotenia dlhých slov sme vypočítali podl'a nasledujúceho vzorca:

Verifikácia výzkumného predpokladu č. 4 
Tabul'ka 3 Výsledky \% vyhodnotenia dlhých slov

\begin{tabular}{|r|l|l|r|r|r|}
\hline $\begin{array}{l}\text { O } \\
\text { zn. } \\
\text { texto } \\
\text { v }\end{array}$ & $\begin{array}{r}\text { ext } \\
1\end{array}$ & $\begin{array}{l}\text { ext } \\
\text { ext }\end{array}$ & $\begin{array}{l}\text { T } \\
\text { ext }\end{array}$ & $\begin{array}{l}\text { T } \\
\text { ext } \\
4\end{array}$ & $\begin{array}{l}\text { } \\
\text { Texto } \\
\text { v }\end{array}$ \\
\hline$\%$ & 4 & 4 & 4 & 4 & 45 \\
& 9,58 & 9,07 & 7,83 & 4,64 &, 28 \\
\hline
\end{tabular}

Výzkumný predpoklad VP4 platí, pretože percento dlhých slov $v$ texte je menej ako $50 \%$.
Verifikácia výzkumného predpokladu č. 5

VP5: Vybratá skupina študentov, pre ktorých je učebnica určená z vybratého textu, doplní 13 a viac slov z 22 chýbajúcich slov

Graf 6 ukazuje, kol'ko žiakov z jednotlivých škôl správne doplnilo určitý počet slov. Všetci žiaci splnili minimálnu podmienku 13 správnych slov t. j. $59 \%$ zo všetkých chýbajúcich slov. V priemere najviac správnych slov $(19,7)$ doplnili žiaci so SOŠ SC a najmenej správnych slov $(18,45)$ doplnili žiaci zo SOŠA TT. Zároveň tabul'ka ukazuje aj percentuálne vyjadrenie počtu $\mathrm{k}$ danému počtu správne doplnených z celkového počtu testov vyplnených žiakmi.

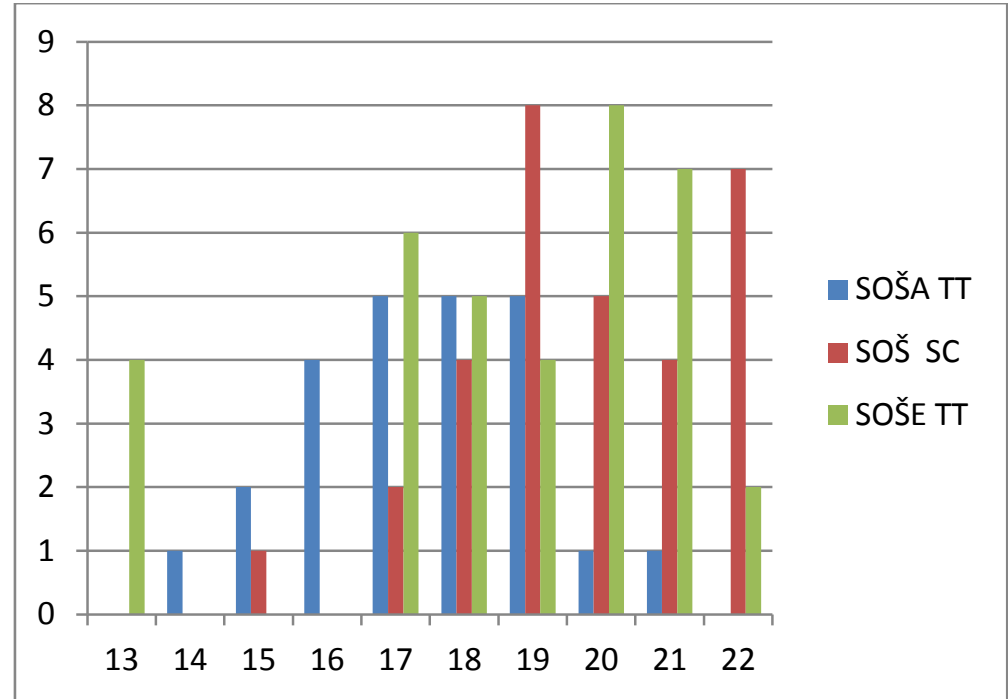

Graf 6 Grafické vyhodnotenie počtu testov s počtami správne doplnených slov po jednotlivých školách

Výzkumný predpoklad VP5 platí, pretože všetci žiaci doplnili správne minimálne 13 slov.

\section{Verifikácia výzkumného predpokladu č.6}

VP6: Hodnota Fog indexu bude 12 alebo menej

Zo štyroch náhodne vybraných textov sme získali údaje pre výpočet Fog indexu. V tabul'ke 4 sú zosumarizované výsledky pre vypočítaný Fog index.

Fog index vypočítame:

Tabul'ka 4 Celkový vypočítaný Fog index

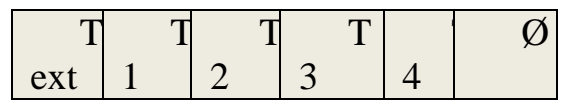

\begin{tabular}{|c|c|c|c|c|c|}
\hline $\mathrm{F}$ & 1 & & 1 & & \\
\hline i & 2,8 & 3,2 & $\begin{array}{l}0,5 \\
6\end{array}$ & 1 & $\begin{array}{l}1,8 \\
9\end{array}$ \\
\hline
\end{tabular}

Výzkumný predpoklad VP6 platí, pretože celkový Fog index vypočítaný zo štyroch náhodne vybraných textov je menej ako 12.

\section{Záver}

Výskum bol zameraný na vyhodnotenie spracovaného e-learningového učebného textu pre 1. ročník nadstavbového štúdia v odbore 6476 4 technicko-ekonomický pracovník. K splneniu uvedeného ciel'a sme sformulovali šest' čiastkových výzkumných predpoladov. $\mathrm{Na}$ základe stanovených ciel'ov sme sformulovali hlavnú hypotézu: "Spracovaný e-learningový text bude zvládnutel'ný v 1. ročníku študijného odboru technicko - ekonomický pracovník na SOŠE 
Trnava. Výberovú vzorku tvorilo 91 žiakov a 22 učitel'ov technických profesijných predmetov na SOŠE TT (škola s nestrojárskym zameraním), SOŠA TT a SOŠ SC (školy so strojárskym zameraním).

Platnost' výzkumných predpokladov (potrebných pre overenie hlavnej hypotézy) je uvedená v tabul'ke 5.

\begin{tabular}{|c|c|c|c|}
\hline $\begin{array}{l}\quad \text { Výzku } \\
\text { mný } \\
\text { predpokla } \\
\text { d }\end{array}$ & $\begin{array}{l}\text { Met } \\
\text { óda }\end{array}$ & $\begin{array}{l}\text { t' Platnos } \\
\text { výzkumné } \\
\text { ho } \\
\text { predpoklad } \\
\text { u }\end{array}$ & $\begin{array}{l}\text { Skúmané } \\
\text { javy }\end{array}$ \\
\hline VP1 & $\begin{array}{l}\text { dota } \\
\text { zník }\end{array}$ & platí & $\begin{array}{l}\quad \text { vlastnosti } \\
\text { e- } \\
\text { learningové } \\
\text { mu testu }\end{array}$ \\
\hline VP2 & $\begin{array}{l}\text { dota } \\
\text { zník }\end{array}$ & neplatí & $\begin{array}{l}\text { úroveň } \\
\text { hodnotenia } \\
\text { vlastností }\end{array}$ \\
\hline VP3 & $\begin{array}{l}\text { dota } \\
\text { zník }\end{array}$ & platí & \begin{tabular}{l}
\multicolumn{1}{c}{ miera } \\
obtiažnosti \\
e- \\
learnigového \\
textu
\end{tabular} \\
\hline VP4 & $\begin{array}{l}\text { dota } \\
\text { zník }\end{array}$ & platí & $\begin{array}{l}\text { čitatel'nos } \\
\mathrm{t}^{\text {e- }} \\
\text { learnigového } \\
\text { textu }\end{array}$ \\
\hline VP5 & $\begin{array}{l}\text { Cloz } \\
\text { e test }\end{array}$ & platí & \begin{tabular}{l}
\multicolumn{2}{r}{ čitatel'nos } \\
$\mathrm{t}$ \\
learnigového \\
textu pre \\
žiakov
\end{tabular} \\
\hline VP6 & $\begin{array}{l}\text { Náh } \\
\text { odne } \\
\text { vybratý } \\
\text { text }\end{array}$ & platí & $\begin{array}{l}\text { čitatel'nos } \\
\mathrm{t}^{\text {e- }} \\
\text { learnigového } \\
\text { textu }\end{array}$ \\
\hline
\end{tabular}

Tabul'ka 5 Súhrn verifikácie výzkumných predpokladov

Ciel'om výskumu bolo zistit' kvalitu elearningového učebného textu učitel'mi technických profesijných predmetov stredných odborných škôl strojárskeho zamerania (SOŠA TT, SOŠ SC) a nestrojárskeho zamerania (SOŠE TT). Výsledky sú zhrnuté vo verifikácii výzkumných predpokladov, kde sú vyhodnotené jednotlivé vlastnosti jednotlivými expertmi. Kvalita textu bola hodnotená podl'a vopred určenej škály $\mathbf{- 2 , - 1 , 0 , 1 , 2}$. Výsledky ukázali, že 22 hodnotiacich učitel'ov technických profesijných predmetov vyhodnotili e-earningový učebný text priemernou škálou hodnotenia 1,48 a v percentuálnej zhode vyhodnotili na úrovni $73,3 \%$ a všetkých 616 vlastností hodnotili v škále od 0 do +2 . Vypočítaný Fog index je úrovni 11,89.

Výskum dokázal, že vytvorený e-learningový text je zvládnutel'ný pre danú ciel'ovú skupinu. Sme presvedčení, že štúdiom tohto predmetu prostredníctvom vytvoreného študijného materiálu nadobudnuté vedomosti a zručnosti zvýšia ich informačnú gramotnost'.

Príspevok je čiastkovým výsledkom riešenia grantovej úlohy podporovanej agentúrou KEGA č. 026STU-4/2011 Model hodnotenia kvality odborného vzdelávania a prípravy na stredných odborných školách v SR.

\section{Literatura}

[1] HRMO, R., TUREK, I. Kl'účové kompetencie I. Bratislava: STU, 2003. 178 s. ISBN 80-227-1881-5.

[2] HUČÍNOVÁ, L. Klíčové kompetence - nová výzva z EU I. Metodický portál 2005. [cit. 20.2.2011]. Dostupné na internete: http://www.rvp.cz/clanek/78/10.

[3] KALAŚ, I.a kol. Rozvoj komplexnej digitálnej gramotnosti budúcich učitel'ov. Moderná informatizácia štúdia a školy pre 21. storočie: [online] 2006. [cit. 12.03.2011].

[4] KUČERKA, D. - HRMO, R. Rozvoj informačnej kompetencie prostredníctvom e-learningu MVVTP 2010 : 15. Medzinárodní vědecká konference Modernizace vysokoškolské výuky technických předmětů. Hradec Králové 1.4.2011. In MVVTP 2011 : Sborník prìspěvků a anotaci mezinárodni védecké konference. Hradec Králové, 24. března 2011. s. 86-92. ISBN 978-80-7435-110-5, ISSN 1214-0554.

[5] KUČERKA, D. Rozvoj informačnej kompetencie prostredníctvom e-learningu: Dizertačná práca. Trnava: STU MtF, 2011. 138 s. MTF-10901-52863.

[6] ODPORÚČANIE

EURÓPSKEHO

PARLAMENTU A RADY z 18. decembra 2006 o Klúčových kompetenciách pre celoživotné vzdelávanie (2006/962/ES) [online]. [cit. 200807-17]. Dostupné na internete: $<$ http://eur- 
lex.europa.eu/LexUriServ/site//sk/j/2006/1_394/1_ 39420061230 sk00100018.pdf $>$.

[7] http://www.edi.fmph.uniba.sk/tmp/asset_cac he/link/0000017748/zaverecna_sprava_a21.pdf.

[8] TURČÁNI, .M. Didaktika vytvárania e-Learning kurzov a materiálov. 2005. [cit.04.4.2011]. Dostupné na internete: http://mcmb.mcmb.sk/ESF/tvorba_ekurzov.htm [9] TUREK, I. Tvorba zrozumitel'ného textu. Experimentálny učebný text grantového projektu VEGA Vysokoškolská pedagogika pre učitel'ov inžinierov podl'a európskych štandardov. Bratislava: Katedra inžinierskej pedagogiky a psychológie, 1997.
[10] ZLÁMAL， J. Didaktika profesního vzdělávání $\mathrm{v}$ širším pedagogickém kontextu. Praha: UJAK, 2009, ISBN 978-80-86723-79-2. Lektoroval: doc. Ing. Pavel Krpálek, CSc.

Roman Hrmo, Doc. Ing. PhD., Katedra inžinierskej pedgogiky, MTF STU, Paulínska 16, 91724 Trnava, SR, tel.:+421 918646045

e-mail: roman.hrmo@stuba.sk Daniel Kučerka, Ing. PhD.,

Katedra inžinierskej pedgogiky, MTF STU, Paulínska 16, 91724 Trnava, SR, tel.: 00421908866180

e-mail: daniel.kucerka@inmail.sk 